\title{
Desain Koalisi Permanen Partai Politik dalam Sistem Pemerintahan Indonesia
}

\author{
Ahmad Siboy \\ Universitas Islam Malang, Indonesia, email: siboysalman@unisma.ac.id
}

\section{Info Artikel}

Submit: 27 Jan 2021

Accepted: 16 Mar 2021

Publish: 29 Mar 2021

Keywords:

Permanent; Coalition

Design; Political Party

Kata Kunci:

Permanen; Desain Koalisi; Partai Politik

\section{(cc) EY-SA}

Lisensi: cc-by-sa

\begin{abstract}
The pattern of political party coalitions that fluctuate ahead of the general election indicates that the coalitions are not built based on substantial interests but pragmatic interests. As a result, the status of each party becomes unclear, which one acts on the side of the government and which one acts as the opposition. This study aims to discuss the options of permanent coalition patterns that can be applied. The research problem of this study was "What is the permanent coalition design that can be applied in the Indonesian government system?". This study used normative legal research with statutory, conceptual, and case-study approaches. The results indicated that a permanent coalition is needed to strengthen the coalition pattern of political parties as a support for the Indonesian government system. The permanent coalition design that can be applied is a two-pole model, in which there will only two coalition groups of political parties: parties supporting the government and parties opposing the government. This two-pole model can be balanced in terms of the power between a coalition of government parties and a coalition of opposition parties. Another design that can be adopted is the coalitions which are established based on the similarity of the ideology of each political party.
\end{abstract}

\begin{abstract}
Abstrak
Pola koalisi partai politik yang berubah-rubah pada tiap menjelang pemilihan umum telah menunjukkan bahwa koalisi partai politik dibangun bukan untuk kepentingan substansial melainkan kepentingan pragmatis. Akibatnya, terjadi ketidakjelasan status partai yang berperan sebagai bagian dari partai pemerintah dan partai yang menjadi oposisi atau pengontrol. Penelitian ini bertujuan untuk memaparkan tentang pilihan pola koalisi permanen yang dapat diterapkan.. Penelitian ini menggunakan jenis penelitian hukum normatif dengan pendekatan peraturan perundang-undangan, pendekatan konsep, dan pendekatan kasus. Hasil penelitian menunjukkan bahwa koalisi permanen dibutuhkan dalam upaya penguatan pola koalisi partai politik sebagai penunjang dari sistem pemerintahn Indonesia. Desain koalisi permanen yang dapat ditempuh ialah dengan model dua kutub dimana hanya terdapat dua kelompok koalisi partai politik yakni partai pendukung pemerintah dan partai oposisi. Pembagian dua kutub ini dapat saja bersifat seimbang antara kekuatan koalisi partai pemerintah dengan kekuatan koalisi partai oposisi. Desain lain yang dapat ditempuh ialah pola koalisi partai politik yang dibentuk berdasarkan kesamaan mazhab atau aliran masing-masing Partai Politik.
\end{abstract}

\section{PENDAHULUAN}

Koalisi partai politik (Parpol) merupakan kerjasama antara dua atau lebih partai politik. Koalisi partai politik dalam sistem multipartai di Indonesia bukanlah merupakan 
suatu keharusan. Koalisi antar Parpol amat bergantung dari kehendak masing-masing Parpol dalam merespon dinamika politik yang berkembang (Haris, 2011; Siboy, 2021). Seringkali, koalisi Parpol terbentuk karena dalam rangka untuk memenuhi ambang batas perolehan suara untuk dapat mengajukan pasanngan calon presiden dan wakil presiden. Ambang batas perolehan suara atau presidential threshold adalah perolehan suara minimal partai politik atau gabungan partai politik untuk dapat mengajukan pasangan calon Presiden dan Wakil Presiden (Edy, 2017; Ghoffar, 2018). Angka ambang batas presidential threhold dapat berubah-rubah pada tiap penyelenggaraan Pilpres sebab angka tersebut sangat bergantung pada dinamika politik dilingkungan pembentuk undang-undang.

Angka presidential threshold dalam Pemilu presiden tahun 2009, pemilu presiden tahun 2014 dan tahun 2019 adalah 20\% kursi DPR RI dan/atau 25\% suara sah nasional. Angka presidential threshold yang cukup tinggi dan tidak dapat dipenuhi oleh satu partai politik inilah kemudian yang memaksa setiap partai politik untuk mencari mitra koalisi supaya dapat mengajukan pasangan calon Presiden/wakil Presiden.

Namun, pola koalisi partai politik yang dibangun hanya atas dasar sekedar memenuhi syarat presidential threshold tersebut telah menjadi fenomena koalisi yang tidak permanen dan ideal. Buktinya, partai politik yang dalam Pemilu Presiden berbeda dukungan pasangan calon presiden dan wakil Presiden namun pasca Pilpres justru berkoalisi dengan pasangan calon presiden dan wakil Presiden yang memenangi Pilpres seperti Partai Gerindra dalam Pemilu Presiden Tahun 2019 (Siboy, 2021).

Tidak terdapatnya pola koalisi yang bersifat permanen tentu menyebabkan beberapa implikasi: pertama, implikasi dari pola koalisi partai politik yang tidak permenen tentu menampakkan minimnya peran substansial partai politik dalam kehidupan berbangsa dan bernegara. Peran substansial partai politik dalam konteks ini ialah bagaimana partai politik menjaga formasi koalisinya baik sebagai koalisi pemenang pemilihan atau koalisi yang kalah dalam pemilihan. Bagi yang kalah maka koalisi tersebut harus tetap berjalan dan menjadi bagian dari koalisi oposisi. Atau koalisi partai yang kalah tidak bergabung dengan koalisi partai pemenang/penguasa.

Kedua, tidak terdapatnya pola koalisi yang bersifat permanen telah menyebabkan partai yang berperan sebagai partai opisisi tidak seimbang dengan partai pendukung pemerintah. Dalam periode pemerintahan tahun 2019-2024 misalnya, hanya terdapat satu partai politik yang menyatakan dengan tegas berada di partai oposisi yakni Partai Keadilan Sejahtera (PKS). Sedangkan Partai Demokrat dan Partai Amanat Nasional (PAN) menyatakan diri tidak berada dalam partai oposisi dan partai pendukung pemerintah. PAN dan Demokrat memposisikan dirinya sebagai partai penengah.

Kondisi partai oposisi yang diperankan oleh PKS tentu tidak seimbang dengan koalisi partai pendukung pemerintah mengingat Parpol koalisi pemerintah terdiri dari lima Parpol yakni Partai Demokrasi Indeonesia Perjuangan (PDI-P), Partai Golkar, Partai Kebangkitan Bangsa (PKB), Partai Nasional Demokrat (Nasdem), dan Partai Persatuan Pembangunan (PPP). Artinya, partai oposisi hanya terdiri dari satu partai dengan jumlah kursi Dewan Perwakilan Rakyat (DPR) sebanyak 50 sedangkan koalisi pemerintah terdiri dari lima Partai dengan jumlah kursi sebanyak 427 yang terdiri dari PDI-P (128), Golkar (85) Gerindra (78), NasDem (59), PKB (58), Demokrat (54), dan PPP (19). Dari sini tampak bahwa partai oposisi sangat minoritas di parlemen. Padahal jika diterapkan pola koalisi permanen maka partai yang berada pada barisan oposisi dapat mengimbangi koalisi pemerintah. Sebab, sebelum partai Gerindra berpindah menjadi partai koalisi pemerintah, partai oposisi terdiri dari Gerindra, PKS, PAN dan Demokrat. Minimnya komposisi kursi partai oposisi tentu menyebabkan kontrol terhadap pemerintah tidak akan kuat bahkan dapat dikatan pemerintah dapat menjalankan kekuasaan tanpa kontrol. 
Ketiga, koalisi non parlemen. Minimnya partai politik yang berposisi sebagai partai oposisi telah menyebabkan munculnya koalisi jalanan atau koalisi non parleman. Koalisi ini biasanya didirikan oleh para tokoh untuk melakukan kritik terhadap pemerintah yang sedang berkuasa. Fenomena munculnya oposisi jalanan ini dapat dilihat dari deklarai Kesatuan Aksi Menyelamatkan Indonesia (KAMI).

\section{METODE}

Penelitian tentang desain pola koalisi partai politik ini mengunakan jenis penelitian yuridis-normatif melalui pendekatan peraturan perundang-undangan, pendekatan kasus, pendekatan sejarah dan pendekatan konsep. Bahan hukum terdiri dari bahan hukum primer, bahan hukum sekunder dan bahan hukum tersier. Teknik pengumpulan bahan hukum ialah dengan inventarisasi dan klasifikasi. Sedangkan teknik analisis yang digunakan adalah teknik analisis deskriptif dan preskriptif.

\section{HASIL DAN PEMBAHASAN}

Koalisi partai politik yang dibangun karena keterpaksaan dan tuntutan kepentingan politik sesaat telah menjadikan pola koalisi partai politik di Indonesia menjadi pola koalisi yang sangat pragmatis dan mengesampingkan hakikat koalisi Parpol yang sejatinya padahal koalisi permanen merupakan suatu keniscayaan (Indra, 2011; Wospakrik, 2018). Oleh karenanya, perlu dilakukan pola desain baru tentang penataan koalisi partai politik di Indonesia. Pola desain yang dapat dijadikan sebagai alternatif untuk mewujudkan koalisi partai politik yang dapat menunjang jalannya sistem pemerintahan Indonesia ialah dengan pola koalisi dengan membagi koalisi partai politik kedalam dua kutub (gabungan partai koalisi pendukung pemerintah dan gabungan partai koalisi oposisi) atau dengan pola pengelompokkan atau koalisi berdasarkan mazhad atau aliran dari tiap partai politik.

\section{Koalisi Dua Kutub}

Model koalisi permanen yang dapat ditempuh ialah model koalisi yang dibelah menjadi koalisi dua kutub. Koalisi dua kutub dalam hal ini ialah seluruh kekuatan partai politik hanya dipisah menjadi dua kelompok saja. Yakni, kelompok partai pendukung pemerintah dan kelompok penentang pemerintah (oposisi). Model pemisahan kedalam dua kutub ini merupakan pengelompokkan atau pola koalisi partai politik yang paling ideal mengingat setiap partai politik dapat menentukan posisinya dengan mudah.

Partai politik cukup mudah dalam menentukan pilihan. Yakni, apakah akan berada dibarisan partai pendukung pemerintah atau di luar pemerintah. Dengan pembagian koalisi kedalam model dua kutub ini maka dapat mencegah perilaku partai politik yang sikapnya sangat pragmatis dan tidak jelas.

Desain pola koalisi kedalam dua kutub ini sangat positif dalam jalannya roda pemerintahan karena sikap dari masing-masing partai politik sudah jelas dari awal. Partai dibarisan oposisi akan berperan sebagai partai yang akan mengontrol dan mengkritisi kebijakan pemerintah sedangkan partai pendukung pemerintah akan mendukung dan membantu menjelaskan kebijakan pemerintah.

Sedangkan komposisi antara partai pendukung dan partai oposisi dapat berupa tiga model. Pertama, seimbang. Komposisi jumlah partai politik antara partai pendukung dan oposisi dapat seimbang. Artinya, jumlah kursi partai politik di Dewan Perwakilan Rakyat (DPR) antara partai politik pendukung dan oposisi fifty-fifty (5050). Komposisi kekuatan antara partai pendukung dan oposisi yang simbang ini tentu akan membuat proses kontrol atas kebijakan pemerintah akan berjalan cukup dinamis dan menjadikan pemerintah berhati-hati dalam mengeluarkan kebijakan sebab apabila 
kebijakan yang dikeluarkan tidak hati-hati maka kebijakan tersebut akan berhadaphadapan dengan partai oposisi di parlemen dimana terdapat potensi kebijakan pemerintah harus ditarik ulang. Dalam hal ini terutama berkaitan dengan kebijakan strategis dan menjadi perhatian publik.

Pada sisi berbeda, komposisi kekuatan pendukung pemerintah dan oposisi yang seimbang ini tentu memiliki potensi dedlock-nya suatu kebijakan. Tatkala kekuatan pemerintah dan oposisi seimbang di DPR maka dedlock-nya suatu kebijakan akan sangat terbuka. Semisal, Presiden menerbitkan suatu Peraturan Pemerintah Pengganti Undang-Undang (Pasal 22 UUD NRI Tahun 1945). Suatu Peraturan Pemerintah Pengganti Undang-undang (Perpu) yang diterbitkan Presiden harus disampaikan ke parlemen untuk dimintai persetujuan. Di DPR inilah nasib Perpu akan ditentukan. Yakni, apakah akan disetujui atau ditolak oleh DPR. Apabila disetujui maka Perpu tersebut dapat menjadi undang-undang sedangkan apabila ditolak maka Perpu tersebut harus dicabut kembali oleh Presiden. Anggota DPR yang berasal dari partai pendukung pemerintah tentu akan menyetujui Perpu yang diterbitkan oleh Presiden untuk dijadikan sebagai undang-undang. Sedangkan anggota DPR yang berasal dari partai oposisi tentu akan menolak Perpu tersebut untuk menjadi undang-undang.

Dalam situasi terjadi polarisasi antara kelompok yang menyetujui dan menolak Perpu tersebut tidak menemui jalan tengah atau kesepakatan maka keputusan akhir harus diambil melalui mekanisme voting. Dalam mekanisme voting tentu yang menentukan pemenangnya adalah jumlah suara antara kelompok yang menyetujui dan yang menolak. Jika komposisi antara partai pendukung dan oposisi seimbang maka keputusan atas Perpu tersebut akan dedlock dan membuat status hukum tetap berlaku sebagaimana mestinya.

Kedua, pemerintah mayoritas. Pola koalisi dua kutub dapat pula terdiri dari komposisi yang tidak seimbang. Kompoisi koalisi partai pendukung pemerintah dapat saja menjadi koalisi partai mayoritas. Yakni, gabungann jumlah partai politik dengan kepemilikan kursi mayoritas di DPR. Dalam hal ini dapat diambil contoh bahwa kekuatan pemerintah dalam penguasaan kursi di DPR mencapai 70\%. Dengan kekuatan ini maka koalisi partai politik pemerintah menjadi partai mayoritas dan gabungan partai politik oposisi hanya memiliki 30\% kursi DPR atau dapat dikatan minoritas.

Jumlah kursi mayoritas yang dimiliki oleh koalisi partai pendukung pemerintah pada hakikatnya merupakan sebuah keharusan demi menjamin kebijakan pemerintah dapat berjalan mulus atau optimal (Manan, 2017). Sebab, dengan modal kursi mayoritas di Parlemen maka akan membuat pemerintah tidak perlu terbebani dengan berbagai akrobat politik DPR terhadap kebijkan pemerintah.

Diakui atau tidak, bahwa dalam kultur politik Indonesia, DPR seringkali melontarkan kritikan terhadap kebijakan pemerintah bukan atas dasar pandangan yang objetif melainkan seringkali lebih pada pertimbangan subyektif karena berstatus sebagai partai oposisi. Koalisi partai oposisi kadangkala melakukan kritik secara membabi buta. Bahkan berupaya semaksimal mungkin untuk menjegal kebijakan strategis pemerintah. Namun, dengan kekuatann kursi mayoritas pemerintah di Parlemen maka pemerintah tidak perlu khawatir karena berdasarkan hitung-hitungan kursi maka koalisi pemerintah pasti menang melawan kubu oposisi.

Keempat. Oposisi mayoritas. Dalam koalisi model dua kutub maka bisa saja koalisi oposisi menjadi koalisi partai mayoritas. Koalisi mayoritas partai oposisi sangat mungkin terjadi di Indonesia karena dalam sistem presidensil seorang Presiden dipilihn langsung oleh rakyat sehingga Presiden yang terpilih dapat saja berasal dari 
koalisi minoritas. Dalam hal ini dapat diambil contoh dalam pemilihan Presiden/wakil Presiden tahun 2014 dimana koalisi tiga partai (PDI-P, Partai Nasdem dan PKB) dapat memenangakan Pilpres dan mengalahkan koalisi partai yang memiliki kursi mayoritas yang meliputi Partai Gerindra, Partai Golkar, PAN, PKS dan Partai Demokrat (Romli, 2018; Ekawati, 2019). Komposisi kursi mayoritas yang dimiliki oleh partai oposisi tentu menjadi koalisi yang sangat mengkhawatirkan pemerintah. Sebab, akan banyak kebijakan pemerintah yang akan kandas ditangan partai oposisi saat berada dalam pembahasan di DPR.

Namun, dalam konteks Indonesia, komposisi mayoritas dalam kubu oposisi sangat sulit bertahan lama (Kunkunrat \& Priangani, 2019). Partai-partai politik di Indonesia lebih nyaman dan terbiasa dalam barisan partai pendukung pemerintah. Dalam hal ini dapat dilihat peta koalisi partai politik sebelum dan sesudah Pilpres Tahun 2014. Pada saat pencalonan Presiden dan wakil Presiden dalam Pilpres tahun 2014 terdapat pasangan calon Presiden Prabowo Subianto-Hatta Radajsa yang didukung oleh Partai Gerindra, PAN, Partai Golkar, PKS, Partai Demokrat dan PPP dan pasangan Joko Widodo-Jusuf Kalla yang didukung oleh PDI-P, Partai Nasdem dan PKB. Peta dukungan ini menunjukkan bahwa pasangan Prabowo Subianto dan Hatta Radjasa didukung oleh 353 kursi atau 63 persen kursi DPR dan Pasangan Joko Widodo-Jusud Kalla didukung oleh 207 atau 37 persen kursi DPR RI. Artinya, mayoritas partai politk atau kursi parlemen mendukung pasangan Prabowo Subianto-Hatta Radjasa. Namun, hasil Pilpres menyatakan bahwa pemenang pemilihan Presiden tahun 2014 adalah pasangan Joko Widodo-Jususf Kalla atau dapat dikatakan pasangan calon yang didukung oleh partai dengan kursi minoritas di DPR RI. Dari sini juga menunjukkan bahwa partai oposisi akan menjadi penguasa di parlemen. Dengan estimasi 63 persen 0posisi berbanding 30 persen kursi partai pendukung pemerintah.

Peta koalisi partai politik tersebut ternyata mengalami perubahan yang signifikan pasca pelantikan Presiden. Partai-partai yang berada dalam barisan oposisi berpindah atau bergabung dengan partai pendukung pemerintah. Partai Amanat Nasional (PAN), Partai Golkar, dan Partai Persatuan Pembangunan (PPP) secara tegas menyatakan berada dalam barisan pendukung pemerintahan Joko Widodo-Jusuf Kalla (Siboy, 2021). Dengan kultur yang demikian maka sangat sulit diharapkan bahwa kubu koalisi oposisi akan menduduki kubu mayoritas.

Pertanyaan selanjutnya ialah berkaitan kapan dimulai atau berlakunya desain koalisi dua kutub tersebut? dalam sistem pemerintahan di Indoneesia, apabila menghendaki adanya pola koalisi dua kutub maka sesungguhnya koalisi tersebut dapat terbangun sejak sebelum dimulainya pemilihan Presiden dan wakil Presiden. Biasanya, menjelang pemilihan Presiden dan wakil Presiden maka partai politik yang satu dengan yang lainnya akan saling mencari mitra koalisi untuk mengajukan pasangan calon Presiden dan wakil Presiden. Proses pencarian mitra koalisi tersebut yang kemudian akan mengkristalisasi koalisi partai politik kedalam dua kubu. Sebab, dengan ketentuan presidential threshold 20 persen kursi DPR atau 25\% suara sah nasional maka potensi jumlah pasangan calon Presiden dan wakil Presiden yang muncul hanya dua pasangan seperti dalam Pemilu tahun 2014 dan Pemilu tahun 2019. Artinya, masing-masing partai politik sudah terpisah menjadi dua kelompok besar yakni gabungan partai politik pendukung pasangan calon A dan gabungan partai politik pendukung Pasangan calon B. Dua kutub koalisi pendukung tiap paslon inilah yang seharusnya dijadikan awal membangun mitra koalisi partai pendukung pemerintah dan partai oposisi. Bagi gabungan partai politik yang memenangkan pemilihan presiden (Pilpres) maka secara otomatis gabungan partai politik tersebut menjadi 
koalisi partai pemerintah sedangkan bagi gabungan partai politik yang calonnya kalah dalam Pilpres maka harus berada dalam barisan partai oposisi. Apabila terdapat tiga pasangan calon dalam Pilpres seperti pada Pilpres Tahun 2009 maka koalisi dua kutub dapat didasarkan kepada polarisasi dukungan partai politik terhadap pasangan calon presiden dan wakil presiden putaran kedua.

Koalisi dua kutub juga dapat dimulai setelah Pilpres atau setelah penetapan oleh Komisi Pemilihan Umum (KPU) tentang pasangan calon Presiden dan wakil Presiden terpilih. Setelah KPU menetapkan siapa yang akan menjadi Presiden dan wakil Presiden Republik Indonesia dalam lima tahun kedepan maka setiap partai politik dapat menentukan kembali kedudukannya yakni apakah akan berada dalam kutub gabungan partai oposisi (diluar pemerintahan) atau akan ikut bergabung menjadi bagian dari koalisi partai pendukung pemerintah. Dua pilihan ini merupakan kebebasan pada setiap parpol.

Dalam dinamika koalisi dua kutub maka model penentuan setelah Pilpres inilah yang paling sering dilakukan. Partai-partai politik menentukan sikapnya secara resmi untuk satu periode lima tahun berikutnya. Yakni, apakah akan berada dalam partai koalisi pemerintah atau oposisi. Model pilihan ini paling sering terjadi karena partaipartai politik di Indonesia cenderung "main aman". Main aman dalam menentukan sikap setelah terpilihnya pasangan calon Presiden dan wakil Presiden karena saat suatu partai politiik menentukan pilihan setelah Pilpres maka ia otomatis akan mendapatkan akibat langsung dari pilihan sikapnya. Partai politik yang menyatakan bergabung dengan pemerintah maka otomatis partai tersebut akan mendapatkan jatah menteri. Sedangkan bagi partai yang memilih berada dalam kutub oposisi maka ia tidak akan mendapatkan jatah menteri di pemerintahan (Admojo, 2016; Loi, 2016).

Pilihan penentuan sikap koalisi atau oposisi setelah Pilpres karena partai yang sebelumnya menjadi lawan dari pasangan calon Presiden dan wakil Presiden yang memenangi Pilpres dapat beralih pilihan atau dapat menjadi partai yang mendukung pasangan calon yang terpilih dalam Pilpres. Perubahan pilihan koalisi sebelum dan sesudah Pilpres merupakan suatu hal yang tidak dilarang dalam regulasi kepemiluan di Indonesia. Model penentuan perubahan koalisi pasca penetapan pemenang Pilpres dapat diambil contoh dari sikap partai Gerindra dalam Pilpres tahun 2019. Sebalum Pilpres, partai Gerindra mencalonkan kadernya yakni Prabowo Subianto-Sandiaga Salahuddin Uno untuk melawan pasangan calon Joko Widodo-K.H. Ma'ruf Amin. Namun setelah pasangan Joko Widodo-KH. Ma'ruf Amin dinyatakan sebagai pasangan calon yang memperoleh suara terbanyak maka partai Gerindra menyatakan bergabung menjadi partai pendukung pemerintah dimana Prabowo Subianto mendapatkan jatah Menteri Pertahanan dan Sandiaga Salahuddin Uno mendapatkan jatah Menteri Ekonomi Kreatif dan Pariwisata.

Yang terpenting dari model desain koalisi dua kutub tersebut ialah bahwa barisan partai pendukung dan partai oposisi telah ditentukan diawal periode pemerintahan sehingga antara partai yang menjadi partai pemerintah dan partai oposisi sudah dapat dipetakan sejak awal pemerintahan. Oleh karenanya, tidak baik kalau kemudian kubu partai koalisi dan oposisi berubah sikap ditengah jalan. Yakni, partai yang diawal pemerintahan berada dibarisan oposisi namun tiba-tiba saat pemerintahan sudah berjalan dua tahun lalu kemudian partai yang berada dalam barisan oposisi tersebut beralih haluan dan mendukung pemerintah.

Perubahan komposisi koalisi ditengah jalan tentu merupakan perubahan peta koalisi yang sangat sulit diterima oleh akal. Sebab, bagaimana mungkin partai politik yang awalnya menentang pemerintah namun tiba-tiba memutuskan berubah haluan 
atau berbalik mendukung pemerintah. Perubahan sikap seperti ini tentu merupakan sikap yang tidak normal mengingat antara koalisi partai pendukung dan penentang pemerintah tentu berada dalam visi dan misi yang berbeda atau berlawanan sehingga saat terjadi perubahan haluan koalisi ditengah jalan maka hal tersebut merupakan suatu keanehan. Ibaratnya, Partai pemerintah memiliki pandangan A sedangakn partai oposisi memiliki pandangan B. Perbedaan pandangan yang semacam ini tentu merupakan perbedaan pandangan yang tidak dapat berubah begitu cepat.

Artinya, perbedaan pandangan tersebut paling singkat berlaku selama satu peirode pemerintahan (lima tahun). Apabila terjadi perubahan sikap partai politik ditengah jalan maka tentu perpindahan barisan koalisi tersebut karena alasan atau kondisi yang tidak substansial. Ada beberapa tesa untuk mengemukakan peralihan barisan koalisi partai politk ditengah jalan atau ditengah periode pemerintahan: Pertama, tekanan. Sangat mungkin partai politik mengalami tekanan dari pemerintah atau penguasa sehingga partai politik yang berada dibarisan oposisi harus mendekat dan bergabung dengan partai pendukung pemerintah. Tekanan semacam ini dapat berupa tekanan kepada para elit Parpol. Tekanan tersebut dapat berupa persoalan pribadi hingga hukum.

Kedua, pecah belah. Perubahan komposisi partai politik khususnya dari partai oposisi menjadi partai koalisi pemerintah juga tidak lepas dari politik pecah belah yang dimainkan oleh kelompok tertentu. Diakui atau tidak, politik pecah belah di internal suatu partai politik untuk mengubah arah dukungan Parpol sudah menjadi fenomena yang tidak bisa dielakkan dalam konteks politik Indonesia. Modus yang digunakan ialah membuat suatu partai politik yang sedang berada dibarisan oposisi mengalami konflik internal. Setelah suatu partai politik mengalami konflik internal maka otomatis kondisi internal parpol akan terpecah menjadi dua bagian yang saling berhadap-hadapan dan perpecahan tersebut juga diiikuti oleh pilihan dari dua kubu yang sedang berkonflik. Yakni, antara kubu yang akan mengalihkan dukungan partai menjadi partai pendukung pemerintah atau tetap menjadi partai oposisi. Konflik yang terjadi dalam internal Partai Golkar, Partai Kebangkitan Bngsa (PKB) dan beberapa partai lain dalam beberapa tahun silam merupakan salah satu bentuk politik pecah belah yang berhasil mengalihkan posisi partai oposisi menjadi partai koalisi pemerintah (Zakiyah, 2017).

Ketiga, jabatan. Perubahan peta dukungan dari posisi sebagai partai oposisi menjadi partai koalisi pendukung pemerintah ditengah jalan juga dipengaruhi oleh deal politik antara penguasa dengan partai politik yang sedang menjadi oposisi. Deal semacam ini ialah dimana partai politik yang awalnya berada pada barisan partai penentang pemerintah mengalihkan dukungannya menjadi partai pendukung pemerintah karena mendapatkan jatah jabatan Menteri atau lain sejenisnya. Biasanya, perubahan sikap ini terjadi setalah kader dari partai oposisi diangkat sebagai Menteri oleh Presiden atau penguasa. Pengangkatan kader suatu Parpol ini diringi dengan konvensasi berupa dukungan Parpol oposisi terhadap pemerintah.

Keempat, tidak tahan menjadi oposisi. Perubahan sikap partai politik dari partai oposisi menjadi partai koalisi pemerintah ditengah jalan juga diakibatkan oleh kondisi atau kebiasaan suatu Parpol yang tidak biasa berada dalam partai oposisi atau seringkali disebut sebagai Partai yang tidak bisa hidup diluar pemerintahan atau di "lahan kering" seperti Partai Golkar yang selalu berada pada barisan partai penguasa.

Namun, ada pula argumentasi positif yang melegitimasi peralihan pola koalisi Partai Politik ditengah jalan. Argumentasi yang digunakan adalah bahwa suatu Parpol mengalihkan dukungan ditengah jalan dengan dalih bahwa ia mengalihkan dukungannya dari partai oposisi menjadi partai koalisi karena setelah sentengah 
periode menjalankan roda pemerintahan maka pemerintah yang sedang berkuasa dianggap berhasil sehingga layak untuk didukung. Walaupun alasan semacam ini merupakan alasan yang terkesan dibuat-buat mengingat kalaupun partai oposisi melihat pemerintah yang sedang berkuasa berhasil menjalankan roda pemerintahan maka bukan berarti harus menjadikan diri mereka beralih posisi dari oposisi menjadi koalisi pemerintah.

\section{Koalisi Berdasarkan Mazhab/Aliran}

Koalisi permanen partai politik di Indonesia juga dapat dikualifikasikan berdasarkan asas dari masing-masing partai. Setiap partai politik pasti memiliki asas mengingat asas adalah landasan ideologis dan falsafah bagi suatu partai politik. Asasasas partai politik di Indonesia tidak boleh bertentangan dengan Pancasila dan Undang-Undang Dasar sebagaimana diatur dalam Pasal 9 ayat (1) Undang-undang Nomor 2 Tahun 2008 yang telah diubah dengan undang-undang nomor 2 Tahun 2011 tentang Partai Politik. Larangan Parpol untuk memiliki asas yang berbeda dari Pancasila tidak lepas dari asas tunggal yang dianut Negara Kesatuan Republik Indonesia yakni Pancasila (Isrok \& Uyun, 2013).

Namun, mengkualifikasikan koalisi partai politik berdasarkan asas merupakan penentuan koalisi partai politik yang sangat sulit dilakukan di Indonesia. Sebab, jika asas Parpol diartikan sebagai turunan dari ideologi maka seluruh Parpol di Indonesia memiliki ideologi yang sama yakni Pancasila. Ideologi Pancasila bagi setiap partai politik bahkan sudah diberlakukan sejak era Presiden Soekarno (Efriza, 2019).

Tatkala koalisi partai politik tidak dapat dikelompokkan berdasarkan kepada asasnya maka pengelompokkan partai politik dapat dikelompokkan berdasarkan kepada aliran atau mazhabnya. Aliran atau mazhab dari masing-masing Parpol pasti berbeda satu sama lain. Perbedaan mazhab diantara partai politik merupakan bentuk kongkrit dalam menerjemahkan ideologi Pancasila kedalam Parpolnya. Bersamaan dengan itu, aliran atau mazhab Parpol juga merefresentasikan asal muasal pendirian suatu partai politik. Dalam konteks aliran politik di Indonesia maka aliran atau mazhab koalisi partai politik dapat dibagi menjadi partai Nasionalis dan partai Religious. Pola pembagian model ini sangat mudah dilakukan. Sebab, Partai-partai di Indonesia sangat mudah diidentifikasi dalam hal aliran religious atau nasionalis. Kemudahan tersebut dapat dilihat dari mayoritas pendiri, kader, lambang dan penamaan struktur kepengurusannya. Semisal, Partai Demokrasi Indonesia Perjuangan (PDI-P) maka dengan mudah partai ini dapat dikelompokkan kedalam Partai Nasionalis. Partai Keadilan Sejahtera (PKS) maka dapat dikelompokkan sebagai partai beraliran religious. Partai Kebangkitan Bangsa (PKB) dapat dikualifikasikan sebagai partai beraliran islam religius karena penamaan struktur partainya menggunakan istilah-istilah islam dan/atau arab seperti sebutan Ketua Dewan Tahfidz dan Ketua Dewan Syuro. Partai Persatuan Pembangunan (PPP) maka secara kasatmata dapat dikualifikasi sebagai partai islam religious karena lambang partai ini menggunakan lambang tempat menghadap ummat muslim ketika sholat (Ka'bah).

Namun, pengelompokkan atau pola koalisi Partai Politik berdasarkan Asas Pancasila-Mazhab/aliran nasionalis dan religious harus sangat hati-hati mengingat pembagian pola koalisi model ini sangat berpotensi membangun ruang terjadinya konflik Suku, Agama, Ras, Antar Golongan (SARA). Konflik yang tentu sangat tidak diharapkan karena dapat memicu terjadinya konflik horizontal bagi seluruh rakyat Indonesia. Sikap kehati-hatian diperlukan karena dalam dinamika politik yang sangat dinamis maka politik berbasis SARA sangat mungkin disulut oleh para elite politik. 
Pemilihan kepala daerah (Pilkada) untuk Daerah Khusus Ibukota Jakarta Tahun 2017 merupakan dinamika politik electoral yang sangat sarat dengan politisasi aliran.

Setelah pola desain dalam upaya mempermanenkan koalisi tersebut ditentukan maka hal selanjutnya yang perlu diatur ialah mengenai masa atau periodisasi masa koalisi. Terdapat dua pilihan masa koalisi yang dapat dijadikan legal policy oleh pembentuk undang-undang. Yakni, Pertama, selamanya. Model koalisi yang bersifat permanen ini adalah model koalisi dimana partai-partai politik berkoalisi atau berkelompok tanpa mengenal batas waktu dan posisi baik akan berkedudukan sebagai partai pendukung pemerintah atau oposisi. Koalisi permanen model ini ialah sekelompok partai politik yang tetap bersatu meskipun koalisinya akan memenangi Pemilihan Presiden atau kalah. Dalam model koalisi ini dibutuhkan konsistensi sikap dari seluruh partai politik yang berkoalisi. Artinya, ketika barisan koalisinya kalah dalam Pilpres maka otomatis berkenan berada dibarisan oposisi dan tidak tergoda dengan tawaran bergabung dengan kelompok Partai yang memenangi Pilpres.

Kedua, periodisasi pemerintahan. Pilihan masa koalisi yang kedua ialah berdasarkan periodisasi pemerintahan. Periodisasi pemerintahan yang berlaku di Indonesia adalah tiap lima tahun sesuai dengan periodisasi pemilihan umum. Model koalisi semacam ini adalah model koalisi dimana gabungan partai politik tetap berada dalam barisan koalisi atau mengikat janji untuk berkoalisi selama satu periode penuh atau lima tahun sehingga diantara anggota koalisi partai politik tidak akan terjadi perpecahan ditengah jalan. Semisal, sebanyak lima partai politik menyatakan berkoalisi untuk periode pemerintahan 2019-2024 maka kelima partai politik tersebut bersamasama selama lima tahun baik sebagai koalisi partai oposisi atau koalisi partai pendukung pemerintah.

\section{KESIMPULAN}

Koalisi partai politik merupakan sebuah keniscayaan bagi partai politik di Indonesia. Koalisi dibutuhkan dalam rangka untuk memperkuat sistem pemerintahan Indonesia yang berada dalam sistem multi partai. Namun, pola koalisi yang terbangun justru atas dasar kepentingan pragmatis semata atau hanya demi memenuhi persyaratan agar dapat mengajukan pasangan calon Presiden dan wakil Presiden dan/atau untuk mendapatkan power sharing berupa jabatan menteri di pemerintahan. Akibatnya, seringkali terjadi perubahan arah koalisi partai politik ditengah jalan. Partai-partai yang sebelumnya berada dalam koalisi yang berhadap-hadapan berbalik menjadi partai mitra koalisi (kawan). Oleh karenanya, perlu desain ulang tentang pengaturan pola koalisi partai politik di Indonesia menuju koalisi partai politik yang permanen. Desain untuk menciptakan koalisi yang permanen dapat ditempuh melalui dua pola yakni pembagian koalisi partai politik kedalam dua kutub atau hanya terdapat koalisi partai oposisi dan partai pendukung pemerintah. Bentuk desain lain yang dapat dipilih ialah pola pembagian koalisi yang didasarkan kepada mazhab atau aliran dari masing-masing partai politik. Bersamaan dengan itu, masa atau periodisasi koalisi juga harus ditentukan dengan jelas apakah periodisasi koalisi partai politik bersifat abadi atau hanya berdasarkan periodisasi pemerintahan.

\section{DAFTAR RUJUKAN}

Admojo, T. (2016). Peran Partai Oposisi di Parlemen Pasca Pemilu Presiden 2014. Jurnal Politik, 1(2), 283-315. https://doi.org/10.7454/jp.v1i2.18

Edy, M. L. (2017). Konsolidasi Demokrasi Indonesia: (Original Intent Undang-Undang Pemilu). RMBooks. 
Efriza, N. (2019). Eksistensi Partai Politik Dalam Persepsi Publik [The Existence of The Political Parties in Public Perception]. Jurnal Politica Dinamika Masalah Politik Dalam Negeri Dan Hubungan Internasional, 10(1), 17-38. https://doi.org/10.22212/jp.v10i1.1314

Ekawati, E. (2019). Peta Koalisi Partai Politik di Indonesia pada Pemilihan Presiden Era Reformasi. JPPUMA: Jurnal Ilmu Pemerintahan Dan Sosial Politik UMA Uournal of Governance and Political Social UMA), 7(2), 160-172. https://doi.org/10.31289/jppuma.v7i2.2680

Ghoffar, A. (2018). Problematika Presidential Threshold: Putusan Mahkamah Konstitusi dan Pengalaman di Negara Lain. Jurnal Konstitusi, 15(3), 480-501. https://doi.org/10.31078/jk1532

Haris, S. (2011). Koalisi Dalam Sistem Demokrasi Presidensial Indonesia: Faktor-faktor Kerapuhan Koalisi Era Presiden Yudhoyono. Jurnal Penelitian Politik, 8(1), 1-14. https://doi.org/10.14203/jpp.v8i1.473

Indra, M. (2011). Gagasan Penyederhanaan Jumlah Partai Politik Dihubungkan Dengan Sistem Pemerintahan Republik Indonesia. Jurnal Ilmu Hukum, 2(2), 1-15. https://doi.org/10.30652/jih.v2i02.1020

Isrok, \& Uyun, D. Al. (2013). Ilmu Negara: Berjalan Dalam Dunia Abstrak (2nd ed.). UB Press.

Kunkunrat, \& Priangani, A. (2019). Partai Politik Dan Inkonsistensi Koalisi Dalam Pemilu 2014 Dan 2019. Paradigma POLISTAAT Jurnal Ilmu Sosial Dan Ilmu Politik, 2(2), 7988. https://doi.org/10.23969/paradigmapolistaat.v2i2.2110

Loi, M. (2016). Politisasi Kabinet Kerja Indonesia Hebat Jokowi-Jk. JISIP: Jurnal Ilmu Sosial Dan Ilmu Politik, 5(1), 18-26. https://doi.org/10.33366/jisip.v5i1.214

Manan, F. (2017). Relasi Eksekutif - Legislatif Dalam Sistem Presidensial Multipartai di Indonesia. Jurnal Wacana Politik, 2(2), 98-112. https://doi.org/10.24198/jwp.v2i2.14198

Romli, L. (2018). Koalisi dan Konflik Internal Partai Politik pada Era Reformasi. Jurnal Politica Dinamika Masalah Politik Dalam Negeri Dan Hubungan Internasional, 8(2), 95-118. https://doi.org/10.22212/jp.v8i2.1138

Siboy, A. (2021). Implikasi Pola Koalisi Partai Politik Terhadap Dinamika Penyelenggaraan Pemilihan Presiden Indonesia. Perspektif Hukum, 21(1), 36-58. https://doi.org/10.30649/phj.v21i1.301

Wospakrik, D. (2018). Koalisi Partai Politik Dalam Sistem Presidensil di Indonesia. Papua Law Journal, 1(1), 142-161. https://doi.org/10.31957/plj.v1i1.585

Zakiyah, Q. M. (2017). Partai Politik Dan Koalisi Pemerintahan (Studi atas Dampak Konflik Elite Partai GOLKAR Tahun 2014-2016 terhadap Dukungan Pada Pemerintahan Joko Widodo-Jusuf Kalla). UIN Syarif Hidayatullah Jakarta. 